\title{
Criança / Child
}

https://doi.org/10.21814/uminho.ed.36.14

\section{Hanne Warming}

Roskilde University, Denmark 



\section{Criança}

Na Sociologia da Infância, o conceito de "criança" representa a população dos mais novos. Alguns pesquisadores da infância utilizam-no para se referirem a pessoas entre 0 a 17 anos, enquanto outros o utilizam para um subgrupo de idade dentro deste grupo - argumentando que devemos usar conceitos mais matizados, como bebés, crianças pequenas, adolescentes, etc.

A justificação para a utilização do conceito para a população total de 0 a 17 anos emergiu de abordagens sociológicas no campo dos estudos da infância, que reconhecem a infância, não apenas como uma fase da vida mas, também, como uma dimensão da estrutura social. Assim, o conceito de "criança" aborda uma posição social (desprivilegiada). Um conceito relacionado que também considera a infância como uma característica estrutural da sociedade é o de "ordem geracional", inspirado pelo conceito feminista de "ordem de género". O conceito de "criança", diz respeito, portanto, a uma posição na ordem social (geracional), que é moldada por meio de construções sociais binárias de crianças como devires e adultos como seres, que envolve uma alteridade implícita das crianças, resultando em desigualdade e discriminação do outro, paralelas à discriminação de mulheres, minorias étnicas etc. O conceito de "geração" refere-se a "processos" materiais, sociais e culturais de alteridade por meio dos quais os indivíduos adquirem a qualidade social de "infantilidade" e o estatuto de "criança" numa dialética com o "adulto" e o "estatuto" de "adulto" (Alanen, 2011, p. 163).

A perspetiva esboçada acima foi criticada por ser excessivamente estruturalista; no entanto, pode-se argumentar que essa crítica se baseia numa visão (excessivamente) estruturalista da ordem social como fixa. Assim, a partir da perspetiva da ontologia Bourdieusiana, que sustenta os conceitos de ordem geracional e generationing originalmente desenvolvidos por Alanen e Mayall, qualquer ordem social é apenas temporariamente fixada, podendo, tais fixações, diferir de campo para campo. Assim, nessa perspetiva, o significado de ser criança não é apenas cultural e historicamente específico, mas também pode variar entre diferentes contextos. A partir de uma perspetiva pós-estruturalista, a ordem social é continuamente remodelada, desafiada e potencialmente alterada por meio de negociações (que podem ser verbais) ou de ações. Visto de ambas as perspetivas sobre ordens sociais, 
desordem e processos de ordenação, o significado de ser criança não tem uma essência fixa, além da dialética com o "adulto", que não tem significado fixo - e mesmo essa dialética pode ser desafiada.

Outra crítica foi levantada por James e James (2004), que apontaram para o risco de cegueira no que concerne ao impacto de outras categorias como género, classe e etnia. Este é um ponto importante, mas não implica que a categoria "criança", definida a partir da perspetiva da ordem geracional e da geração, não seja relevante e sólida nas análises da infância e da vida das crianças, nem mais geralmente nas análises da estrutura social e dos processos de mudança social. Em vez disso, o oposto aplica-se: exatamente por causa da abordagem dialética social (pós) estrutural da categoria criança, as análises desta perspetiva também revelarão insights sobre a categoria adulta e a posição social. No entanto, é importante assinalar que existem muitas infâncias diferentes e que a negociação do que significa ser uma criança específica se cruza com as negociações sobre o significado de outras categorias.

Närvanen e Näsman (2004) levantaram uma terceira objeção à concetualização de ordem geracional e geração relativamente à categoria "criança". Os autores argumentam que o dualismo criança - adulto deve ser considerado como um continuum, tanto na vida de um indivíduo, quanto na posição social. No entanto, se, como Närvanen e Näsman (ibidem) sugerem, se substituirmos "geração" e "criança" por "fase de vida" e "idade" enquanto categorias analíticas, corremos o risco de omitir a atenção crítica necessária à discriminação contra crianças em geral, e à infância como característica estrutural da sociedade. Assim, em vez de substituir um conceito por outro, podemos incluir a idade como uma categoria adicional e diferenciadora na análise interseccional para compreender, tanto a homogeneidade quanto a heterogeneidade (idade) na análise da infância das crianças e das negociações temporariamente contextualizadas da posição da criança.

Por fim, Prout (2005) criticou a forma como "criança" é concetualizada dentro da ordem geracional e das perspetivas geracionais, apontando que tal ignora os processos corporais e biológicos da vida devido à ênfase no social e à ânsia de criticar a psicologia do desenvolvimento tradicional e os modelos sociológicos (estrutural-funcionalistas) iniciais da criança. Enquanto nos primeiros estádios dos estudos da infância esta foi uma postura necessária e apropriada que destacou o argumento sociológico de que "criança" constituía uma posição social, a tarefa desafiadora hoje é corrigir essa omissão do corpo e dos processos biológicos da vida numa concetualização 
sociológica da criança, sem perder de vista que "criança" constitui uma posição social.

\section{Child}

In the sociology of childhood, the concept of "child" denotes the population of young people. Some childhood researchers use it to address people aged 0-17 years, while others reserve it for a sub-age-group within this group or argue that we should use more nuanced concepts such as babies, young children, teens, teenagers etc.

The rationale for using the concept to address the total population aged 0-17 emerged from sociological approaches within the field of childhood studies, which acknowledge childhood not only as a life phase, but also as a dimension of the social structure. Thus, the concept of "child" addresses a (unprivileged) societal position. A related concept that also regards childhood as a structural feature of society is the concept of the "generational order", which was inspired by the feminist concept of "gender order". The concept of "child" therefore addresses a position in the social (generational) order, which is shaped through binary social constructions of children as becomings and adults as beings, and which involves an implicit othering of children, resulting in inequality and discrimination parallel to the othering and discrimination of women, ethnic minorities etc. The concept of "generationing" refers to these "material, social and cultural othering processes through which individuals acquire the social quality of 'childness' and 'child' status in a dialectic with 'adultness' and 'adult' status" (Alanen, 2011, p. 163).

The perspective outlined above has been criticized for being overly structuralist; however, this critique may be debated based on an overly structuralist view of the social order as fixed. Thus, seen from the perspective of the Bourdieusian ontology that underpins the concepts of generational order and generationing as originally developed by Alanen and Mayall, any social order is only temporarily fixed. Further, such social orders may differ from field to field. Thus, from this perspective, the meaning of being a child is not only culturally and historically specific, but may also vary across different contexts. From a poststructuralist perspective, the social order is continuously reshaped, challenged and potentially changed through negotiations (which may be verbal), or through actions. Seen from both these perspectives on social order, disorder and ordering processes, the meaning of being a child does not have a fixed essence, other than the 
dialectic with "adult", which has no fixed meaning - and even this dialectic may be challenged.

Another criticism was raised by James and James (2004), who pointed to the risk of blindness to the impact of other ordering categories such as gender, class and ethnicity. This is an important point; however, it does not imply that the category "child", as defined from the generational order and generation perspectives, is not relevant and sound in analyses of childhood and children's lives, nor more generally in analyses of the social structure and social change processes. Rather, the opposite applies: exactly because of the dialectic social (post)structural approach to the child category, analyses from this perspective will also reveal insights about the adult category and social position. However, it is an important point that there are many different childhoods, and that the negotiation of what it means to be a specific child intersects with negotiations over the meaning of other categories.

Närvanen og Näsman (2004) raised a third objection to the generational order and generationing perspectives conceptualization of the category "child". They argued that the child - adult dualism must be regarded as a continuum, both in an individual's life and as a societal position. However, if, as Närvanen \& Näsman (ibidem) suggest, we replace "generation" and "child" with "life phase" and "age" as analytical categories, we risk omitting the necessary critical attention to discrimination against children in general, and to childhood as a structural feature of society.

Finally, Prout (2005) has criticized the way in which "child" is conceptualized within the generational order and generationing perspectives, pointing out that this ignores the body and biological life processes because of its emphasis on the social and its eagerness to criticize traditional development psychological and early sociological (structural-functionalistic) models of the child. While in the early stages of childhood studies this was a necessary and appropriate stance that highlighted the sociological point that "child" constituted a societal position, the challenging task today is to redress this omission of the body and biological life processes in a sociological conceptualization of the child, without missing the point that "child' constitutes a societal position. 


\section{Referências / References}

Alanen, L. (2011). Critical Childhood Studies? Childhood, 18 (2), 147-150.

James, A. \& James, A. L. (2004). Constructing Childhood: Theory, Policy and Social Practice. London: Palgrave Macmillan.

Närvänen, A. \& Näsman, E. (2004). Childhood as Generation or Life Phase. Childhood, 12 (1), 71-91.

Prout, A. (2005). The Future of Childhood. Towards the Interdisciplinary Study of Childhood. London and New York: Routledge. 